\title{
Nursing diagnosis related to the coronavirus pandemic infections in the Brazilian population
}

\author{
Diagnóstico de enfermagem relacionado à pandemia de infecções por coronavírus na população brasileira
}

Diagnóstico de enfermería relacionado a la pandemia de infecciones por coronavirus en la población brasileña

Polyanne Aparecida Alves Moita Vieira' ORCID: 0000-0001-7499-4931

Cristine Alves Costa de Jesus' ORCID: 0000-0002-8638-4468

'Universidade de Brasília. Brasília, Distrito Federal, Brazil.

How to cite this article:

Vieira PAAM, Jesus CAC. Nursing diagnosis related to the coronavirus pandemic infections in the Brazilian population. Rev Bras Enferm. 2022;75(Suppl 1):e20200573. https://doi.org/10.1590/0034-7167-2020-0573

Corresponding author:

Polyanne Aparecida Alves Moita Vieira

E-mail:polymoita@gmail.com

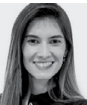

EDITOR IN CHIEF: Dulce Barbosa ASSOCIATE EDITOR: Marcos Brandão
Approval: 09-19-2021

\begin{abstract}
Objective: To reflect on the nursing diagnoses in individuals, families or collectivity facing the pandemic of COVID-19. Methods: The Developing Nurses'Thinking model was considered as a theoretical framework, and the phases of critical thinking skills were applied to the identification of nursing diagnoses in the general population in the face of the pandemic. Results: The systematic application of the seven critical thinking skills of the proposed model and the presentation of 13 nursing diagnoses and their respective indicators were performed. Final considerations: It is necessary to recognize the importance of incorporating nursing diagnoses and clinical reasoning in all contexts of professional nursing care. Further discussion on the subject is also necessary, with the aim of validating the suggested nursing diagnoses, as well as their indicators, in more in-depth studies of experience reports and clinical cases. Descriptors: Nursing Process; Nursing Diagnosis; Coronavirus Infections; Population; Standardized Nursing Terminology.
\end{abstract}

\section{RESUMO}

Objetivo: Refletir sobre os diagnósticos de enfermagem em pessoas, famílias ou coletividade diante do enfrentamento da pandemia de COVID-19. Métodos: Considerou-se como marco teórico o modelo Developing Nurses' Thinking, e foram aplicadas as fases de habilidades de pensamento crítico para a identificação de diagnósticos de enfermagem na população geral diante da pandemia. Resultados: Realizou-se a aplicação sistemática das 7 habilidades de pensamento crítico do modelo proposto e a apresentação de 13 diagnósticos de enfermagem e seus respectivos indicadores. Considerações finais: Faz-se necessário reconhecer a importância da incorporação dos diagnósticos de enfermagem e do raciocínio clínico em todos os contextos de cuidado profissional da enfermagem. Também são necessárias maiores discussões sobre a temática, com o objetivo de validar os diagnósticos de enfermagem sugeridos, bem como os seus indicadores, em estudos mais aprofundados de relatos de experiência e casos clínicos. Descritores: Processo de Enfermagem; Diagnóstico de Enfermagem; Infecções por Coronavírus; População; Terminologia Padronizada em Enfermagem.

\section{RESUMEN}

Objetivo: Reflexionar acerca de los diagnósticos de enfermería en personas, familias o colectividad frente a la pandemia de COVID-19. Métodos: Considerado como marco teórico el modelo Developing Nurses' Thinking, y aplicadas las fases de habilidades de pensamiento crítico para la identificación de diagnósticos de enfermería en la población general frente a la pandemia. Resultados: Se realizó la aplicación sistemática de las 7 habilidades de pensamiento crítico del modelo propuesto y la presentación de 13 diagnósticos de enfermería y sus respectivos indicadores. Consideraciones finales: Se hace necesario reconocer la importancia de la incorporación de los diagnósticos de enfermería y del raciocinio clínico en todos los contextos de cuidado profesional de la enfermería. También son necesarias mayores discusiones acerca de la temática, con el objetivo de validar los diagnósticos de enfermería sugeridos, así como sus indicadores, en estudios más profundados de relatos de experiencia y casos clínicos. Descriptores: Proceso de Enfermería; Diagnóstico de Enfermería; Infecciones por Coronavirus; Población; Terminología Normalizada de Enfermería. 


\section{INTRODUCTION}

In a global context, we live a historical moment characterized by a public health emergency of international importance declared by the World Health Organization (WHO), a situation caused by the severe acute respiratory syndrome coronavirus 2, SARS-CoV-2. A Public Health Emergency of International Concern (PHEIC) is the Organization's highest level of alert, as set out in the International Health Regulations ${ }^{(1)}$. In March 2020, COVID-19, a disease caused by this virus, was characterized by the WHO as a pandemic.

Also under the International Health Regulations (IHR), PHEIC is considered"an extraordinary event that may constitute a public health risk to other countries due to the international spread of disease; and potentially requires an immediate and coordinated international response ${ }^{\prime \prime(1)}$.

Taking into account that emerging and re-emerging infectious diseases are constant challenges for public health worldwide, in the Brazilian context several measures are being adopted to contain the spread of SARS-CoV-2, one of them being the qualification of care for these cases. In this context, and according to the Federal Council of Nursing (Cofen), nursing has an essential role in the aspect of detection and evaluation of suspected cases, not only because of its technical capacity, but also because it is the largest professional category of health care and the only one that is by the patient's side 24 hours a day ${ }^{(2)}$.

Considering that the nursing process is an intellectual tool for nurses' work that guides the process of clinical reasoning and diagnostic decision making, outcomes and interventions $s^{(3)}$, it is of utmost importance that, in this scenario, nursing understands that the nursing process is also a way of knowing how to be and how to do nursing. They must be prepared to act by implementing the nursing process in situations where professional care occurs in cases of prevention, recovery, and treatment related to the contamination by SARS-CoV- 2 .

According to the Cofen Resolution No. 358/2009, the nursing process is composed of five stages: data collection, nursing diagnosis, planning, implementation, and evaluation. In the nursing diagnosis stage, the use of a uniform, standardized language, in addition to facilitating communication and the use of computerized systems, allows the representation of nursing clinical knowledge( ${ }^{(4)}$.

A nursing diagnosis is a clinical judgment about a human response to health conditions/life processes, or a vulnerability to such response, of an individual, a family, a group, or a community ${ }^{(5)}$. Nurses must identify the diagnoses appropriate to their area of practice, situated within their scope of practice or in accordance with legal regulations, and for which these professionals are competent $t^{(5)}$.

In this context, this article aims to reflect on possible nursing diagnoses in individuals, families or collectivities facing the pandemic of COVID-19, based on the Developing Nurses' Thinking model of critical thinking.

Nursing diagnoses should be made through a grouping of data; and, based on that, an interpretation and consequent clinical judgment and decision-making are made. This reflection used the nursing diagnoses of NANDA-I, version 2018-2020; and, according to this taxonomy, the accuracy of the nursing diagnosis is validated when the nurse can clearly identify and link the defining characteristics to the related factors and/or risk factors found with the patient's assessment. However, the organization says that in practice, you need to consider related/risk factors appropriate for your patient based on theories, literature, supporting research, expert opinion, and your own clinical experience ${ }^{(5)}$.

For the development of nursing diagnoses, data from the virtual health survey "ConVid, Behavior Survey" were used(6); and as a theoretical framework, the Developing Nurses'Thinking educational model, whose objective is to assist in the process of clinical reasoning and critical thinking in the various decisions involved in the nursing process ${ }^{(7)}$.

ConVid is a health survey conducted by the Oswaldo Cruz Institute Foundation (Fiocruz) in partnership with the Federal University of Minas Gerais (UFMG) and the State University of Campinas $(\text { Unicamp })^{(6)}$. It aimed to describe the adherence of the Brazilian population to social restriction measures, investigate changes in work and income status, analyze difficulties in performing routine activities, health conditions, and describe changes in behaviors adopted during the pandemic of COVID-19. The ConVid uses questions validated in health surveys previously applied in Brazil(6).

The ConVid survey data are subdivided into categories, namely: Social Isolation, Infection by the new coronavirus, Socioeconomic impact, Routine activities and work, Caregiver of the elderly, Effects on health status, Access to health services, Mood and healthy behaviors (sedentary lifestyle, physical activity, personal and home hygiene). All category center points were read and analyzed, so that 13 data points with significant percentages were chosen in the ConVid.

Based on the ConVid data survey, the Developing Nurses' Thinking educational model was applied. This model, proposed specifically to conduct the diagnostic reasoning process of students, has four components - patient safety, knowledge mastery, critical thinking processes specific to nursing, and repeated practice - integrated to guide the organization of thinking processes, interpretation of patient data, naming of data interpretation (nursing diagnoses), and development of care plans (nursing interventions and outcomes). Such a model is grounded in the triarchical theory of human intelligence $e^{(7)}$.

The Developing Nurses' Thinking (DNT) model is a teaching methodology whose objective is to guide the nursing student during the evaluation of fictitious or real clinical cases. In this article, the proposal is for guidance regarding the data collected, in order to support clinical reasoning, since the model contributed to the organization of almost imperceptible clues or traces and the identification of accurate diagnoses that support an appropriate care plan ${ }^{(7-8)}$.

For the clinical reasoning development process, the DNT model describes seven critical thinking skills (analysis, pattern application, discrimination, information seeking, logical reasoning, prediction, and knowledge transformation); and ten habits of mind (confidence, contextual perspective, creativity, flexibility, curiosity, intellectual integrity, intuition, open-mindedness, perseverance, and reflection) $)^{(7,9)}$.

Chart 1 demonstrates the Developing Nurses'Thinking model, culturally adapted for Brazil and applied to the analysis of data from the Brazilian population in the context of the pandemic of COVID 19. 
Chart 1 - Developing Nurses'Thinking model, culturally adapted for Brazil and applied to the analysis of nursing diagnoses to the Brazilian population in the context of the pandemic of COVID-19

\begin{tabular}{|c|c|c|}
\hline $\begin{array}{l}\text { Critical } \\
\text { thinking skills }\end{array}$ & $\begin{array}{l}\text { Data from the Brazilian population in the context } \\
\text { of the COVID-19 pandemic according to "ConVid, } \\
\text { Behavior Survey }\end{array}$ & $\begin{array}{l}\text { Habits of } \\
\text { the Mind }\end{array}$ \\
\hline Analysis & \multirow{10}{*}{$\begin{array}{l}\text { 1. Inadequate house hygiene practices; and inadequate } \\
\text { personal hygiene practices arising from the sustained } \\
\text { community spread of SARS-CoV-2 recorded globally. } \\
\text { 2. Exposure to the disease outbreak and high virulence } \\
\text { of SARS-CoV-2. } \\
\text { 3. Social, physical isolation, affective and emotional } \\
\text { deprivation. } \\
\text { 4. Difficulty in establishing relationships } \\
\text { 5. Insufficient recreational activity } \\
\text { 6. Lack of fitness, boredom and dissatisfaction with the } \\
\text { situation } \\
\text { 7. Apprehension, feelings of alarm, fear, panic, dread and } \\
\text { terror } \\
\text { 8. Threat to the present condition and death } \\
\text { 9. Restlessness, insomnia, decreased productivity } \\
\text { 10. Inadequate understanding, social anxiety, and } \\
\text { negative perception of recommended health care } \\
\text { strategy } \\
\text { 11. Insufficient knowledge } \\
\text { 12. Ineffective strategies for stress relief } \\
\text { 13. Lack of adherence to health activities }\end{array}$} & Trust \\
\hline \multirow{3}{*}{$\begin{array}{l}\text { Applying } \\
\text { Standards }\end{array}$} & & $\begin{array}{l}\text { Contextual } \\
\text { perspective }\end{array}$ \\
\hline & & Creativity \\
\hline & & Flexibility \\
\hline Discrimination & & Curiosity \\
\hline $\begin{array}{l}\text { Information } \\
\text { seeking }\end{array}$ & & $\begin{array}{l}\text { Intellectual } \\
\text { integrity }\end{array}$ \\
\hline $\begin{array}{l}\text { Logical } \\
\text { reasoning }\end{array}$ & & $\begin{array}{l}\text { Intuition: } \\
\text { pattern } \\
\text { recognition }\end{array}$ \\
\hline Prediction & & $\begin{array}{l}\text { Open- } \\
\text { mindedness }\end{array}$ \\
\hline & & Perseverance \\
\hline $\begin{array}{l}\text { Knowledge } \\
\text { transformation }\end{array}$ & & Reflection \\
\hline
\end{tabular}

\begin{tabular}{|c|c|c|c|c|}
\hline \multicolumn{5}{|c|}{ Data analysis } \\
\hline $\begin{array}{l}\text { Insufficient recreational activity } \\
\text { Lack of fitness, boredom, and } \\
\text { dissatisfaction with the situation } \\
\text { Inadequate understanding, social } \\
\text { anxiety, and negative perception of } \\
\text { recommended health care strategy } \\
\text { Insufficient knowledge }\end{array}$ & $\begin{array}{l}\text { Lack of } \\
\text { adherence to } \\
\text { health activities }\end{array}$ & $\begin{array}{l}\text { Apprehension, sense of } \\
\text { alarm, fear, panic, dread } \\
\text { and terror } \\
\text { Threat to present } \\
\text { condition and death } \\
\text { Restlessness, insomnia, } \\
\text { decreased productivity } \\
\text { Ineffective strategies for } \\
\text { stress relief }\end{array}$ & $\begin{array}{l}\text { Inadequate household } \\
\text { hygiene practices; and } \\
\text { inadequate personal hygiene } \\
\text { practices arising from the } \\
\text { sustained community spread } \\
\text { of SARS-CoV-2 recorded } \\
\text { globally } \\
\text { Exposure to disease } \\
\text { outbreak and high virulence } \\
\text { of SARS-CoV-2 }\end{array}$ & $\begin{array}{l}\text { Social, physical } \\
\text { isolation, } \\
\text { affective and } \\
\text { emotional } \\
\text { deprivation } \\
\text { Difficulty in } \\
\text { establishing } \\
\text { relationships }\end{array}$ \\
\hline
\end{tabular}

\begin{tabular}{|c|c|c|c|c|}
\hline \multicolumn{5}{|c|}{ Application of Standards - NANDA-I Domains } \\
\hline 1. Health promotion & 4. Activity/Rest & $\begin{array}{l}\text { 9. Coping/ } \\
\text { Tolerance to stress }\end{array}$ & 11. Safety and Security & 12. Comfort \\
\hline \multicolumn{5}{|c|}{ Breakdown - NANDA-I Nursing Diagnoses } \\
\hline $\begin{array}{l}\text { Poor community health } \\
\text { Involvement in recreational } \\
\text { activities decreased } \\
\text { Risk-prone health behavior } \\
\text { Ineffective health control } \\
\text { Ineffective protection }\end{array}$ & Self-neglect & $\begin{array}{l}\text { Fear } \\
\text { Anxiety } \\
\text { Ineffective coping }\end{array}$ & $\begin{array}{l}\text { Risk of Contamination } \\
\text { Risk of Infection }\end{array}$ & $\begin{array}{l}\text { Risk of } \\
\text { loneliness } \\
\text { Social isolation }\end{array}$ \\
\hline
\end{tabular}

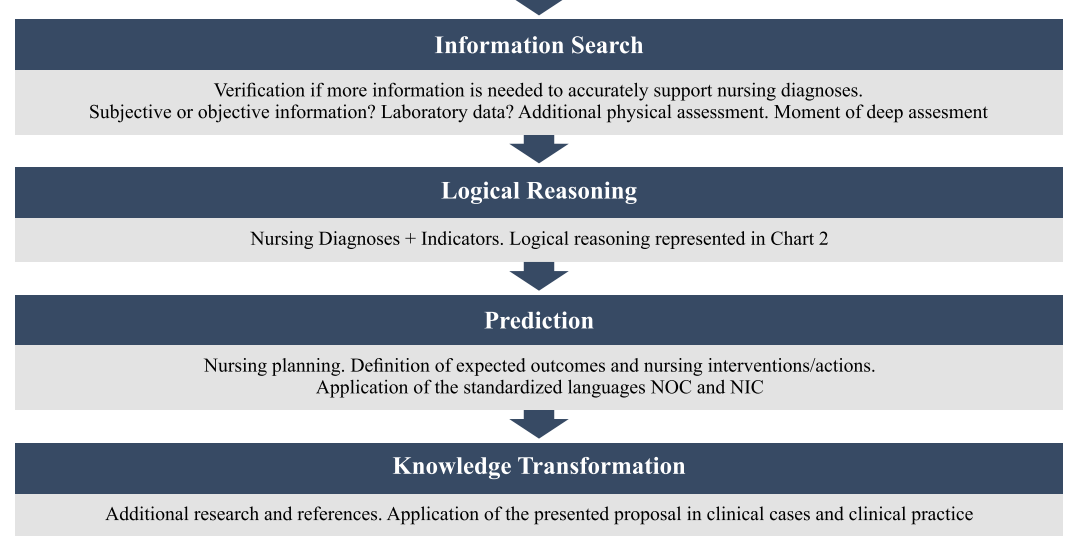

Figure 1- Applying the critical thinking skills of the Developing Nurses'Thinking model to elaborate nursing diagnoses of the general population in the context of the pandemic of COVID-19
The critical thinking skills were systematically applied around the Brazilian population data obtained in the "ConVid, Behavior Survey", a course that will be detailed below.

\section{Critical thinking skills}

The skill of analysis concerns the perception of the whole, which can be separated into parts in order to examine the complete content ${ }^{(7)}$. In this case, data found in ConVid's research was extracted and grouped into five groups, representing similar terms and understandings.

The application of standards is the comparison of scenarios with established rules, current legislation, social, professional or personal standards. To prepare the nursing diagnoses of this reflection, the standard used was based on the domains of NANDA-I, version 2018/2020. NANDA-I is in Taxonomy II, thus having 13 domains and 47 classes, according to the model proposed by Marjory Gordon. The data extracted were related to the following domains: Safety/Protection; Comfort; Health Promotion; Coping/Tolerance to Stress and Activity/Rest.

Next, the use of the discrimination skill was addressed. Discrimination is the perception of differences or similarities between pathologies, signs and symptoms, situations, cases, etc ${ }^{(7)}$. At this point, the nursing diagnoses of certain domains were studied, with a view to understanding the definitions and reading the indicators. For each data, or group of data, possible nursing diagnoses from NANDA-I were selected.

Another step in the critical thinking process is the search for information, which concerns the theoretical, practical, folkloric, mythical grounding of information that may be relevant, captured from the various media, to support the case under analysis ${ }^{(7)}$. For this step, there was a deep assessment, i.e., a more detailed and in-depth investigation of data that could support and provide accuracy to the selected diagnoses. This investigation was done using the virtual health survey "ConVid, Behavior Survey" and other specific references focused on each nursing diagnosis.

Logical reasoning skills are the conclusions reached based on evidence or justified by evidence, quick perception about the fact, perception of the sequence of events until the objective is reached ${ }^{(7)}$. The use of this skill occurred through the application of the indicators to each of the nursing diagnoses, so that the sequence demonstrated a conclusion of 
Chart 2 - NANDA-I nursing diagnoses for the general population in the context of pandemic COVID-19

\begin{tabular}{|c|c|}
\hline Risk Diagnostics & Risk factors \\
\hline $\begin{array}{l}\text { Contamination } \\
\text { rate }\end{array}$ & $\begin{array}{l}\text { Inadequate household hygiene practices; inadequate personal } \\
\text { hygiene practices resulting from the sustained community spread of } \\
\text { SARS-CoV-2 recorded globally }\end{array}$ \\
\hline Infection rate & Exposure to disease outbreak and high virulence of SARS-CoV-2 \\
\hline Risk of loneliness & Social, physical isolation, affective and emotional deprivation \\
\hline $\begin{array}{l}\text { Problem- } \\
\text { focused } \\
\text { diagnostics }\end{array}$ & Related factors and defining characteristics \\
\hline Social isolation & $\begin{array}{l}\text { It is related to the difficulty in establishing relationships (due to the } \\
\text { need to control the spread of the microorganism), characterized by } \\
\text { imposed loneliness (staying at home and not having direct contact } \\
\text { with society). }\end{array}$ \\
\hline Fear & $\begin{array}{l}\text { It relates to the unfamiliar scenario and separation from the } \\
\text { support system characterized by apprehension, feeling of alarm, } \\
\text { fear, panic, fear and terror, state of agitation and muscle tension, } \\
\text { stimuli perceived as threatening, decreased productivity, increased } \\
\text { alertness, state of avoidance, impulsiveness. }\end{array}$ \\
\hline Anxiety & $\begin{array}{l}\text { It relates to interpersonal contagion and threatening present } \\
\text { condition and death characterized by restlessness, insomnia, } \\
\text { decreased productivity, aimless movement, acts as if examining } \\
\text { the environment, irritability, nervousness, uncertainty, agony } \\
\text { and apprehension, facial tension, tremors, increased tension and } \\
\text { sweating, altered concentration and attention, thought blocking, } \\
\text { forgetfulness, worry, and mental rumination. }\end{array}$ \\
\hline $\begin{array}{l}\text { Poor community } \\
\text { health }\end{array}$ & $\begin{array}{l}\text { It relates to inadequate support program (arising from the } \\
\text { pandemic and high spread of the coronavirus) characterized } \\
\text { by health problem and risk of physiological, psychological and } \\
\text { hospitalization states experienced by the world population. }\end{array}$ \\
\hline $\begin{array}{l}\text { Decreased } \\
\text { involvement } \\
\text { in recreational } \\
\text { activities }\end{array}$ & $\begin{array}{l}\text { It relates to insufficient recreational activity (due to the need to } \\
\text { control the spread of microorganism), characterized by lack of } \\
\text { fitness, boredom, and dissatisfaction with the situation. }\end{array}$ \\
\hline $\begin{array}{l}\text { Risk-prone health } \\
\text { behavior }\end{array}$ & $\begin{array}{l}\text { It relates to inadequate understanding, social anxiety and negative } \\
\text { perception of the recommended health care strategy, characterized } \\
\text { by failure to act to prevent health problems, failure to achieve an } \\
\text { optimal sense of control. }\end{array}$ \\
\hline $\begin{array}{l}\text { Ineffective health } \\
\text { management }\end{array}$ & $\begin{array}{l}\text { It relates to insufficient social support, insufficient knowledge about } \\
\text { the therapeutic regimen, characterized by failure to act to reduce } \\
\text { risk factors, difficulty with the prescribed regimen, and failure to } \\
\text { include the treatment regimen in daily life. }\end{array}$ \\
\hline Self-neglect & $\begin{array}{l}\text { It relates to lifestyle choices and learning disabilities, characterized } \\
\text { by lack of adherence to health activities, insufficient environmental } \\
\text { hygiene, and insufficient personal hygiene. }\end{array}$ \\
\hline $\begin{array}{l}\text { Ineffective } \\
\text { coping }\end{array}$ & $\begin{array}{l}\text { It relates to ineffective stress-relieving strategies characterized } \\
\text { by risk-taking behavior, insufficient problem-solving skills, and } \\
\text { destructive behavior toward self and others. }\end{array}$ \\
\hline $\begin{array}{l}\text { Ineffective } \\
\text { protection }\end{array}$ & $\begin{array}{l}\text { It is related to extreme age, immune disorder, and abnormal blood } \\
\text { profile characterized by cough, weakness, fatigue, and impaired } \\
\text { immunity. }\end{array}$ \\
\hline
\end{tabular}

thoughts, since the data initially analyzed were the evidence, etiological factors or risk factors of the chosen diagnoses.

Predictive skill is the ability to envision the proposed plan and the possible consequences $^{(7)}$. The use of this skill is highlighted in the nursing planning stage, and it is suggested for this moment the use of the standardized languages of NOC and NIC, in order to have a link of critical thinking through the nursing process.

Finally, the knowledge transformation skill was used, which is the changing of concepts through knowledge associated with practice and searching for information in scientific media (7). It is imperative that the nursing diagnoses of this reflection be validated by application in educational settings, with the use of clinical cases, as well as in practice settings.

Figure 1 below didactically represents the path taken to identify nursing diagnoses and their indicators, using the critical thinking skills of the DNT model.

Chart 2 describes the proposed nursing diagnoses with their respective indicators (risk factors, related factors and defining characteristics), so that this moment reflected the use of the Logical Reasoning skill of the DNT model ${ }^{(10)}$.

It is noted that five of the diagnoses are from the Health Promotion domain, and the others from the Safety/Protection; Comfort; Activity/Respite; and Coping/Tolerance to Stress domains. The domains found reflect the application phase of the DNT model standards, also demonstrating the pattern of health needs of the population in the current context of the pandemic. That is, they mostly address diagnoses aimed at planning for the prevention and promotion of health, both physical and mental.

The confirmation or non-confirmation of the nursing diagnoses elaborated in this reflection can occur by their systematic application in the Problem Form of the DNT model ${ }^{(7,9)}$, culturally adapted for Brazil, presented below (Figure 2).

\begin{tabular}{|c|c|c|c|c|c|}
\hline \multicolumn{6}{|c|}{ Formulário de problemas:esses podem ser diagnósticos de enfermagem,posslvels problemas médicos ou a descríçao do problema } \\
\hline Problema & $\begin{array}{c}\text { Confirmação } \\
\text { Características definidoras } \\
\text { Achados da avaliação que apoiam a identificação do } \\
\text { problema (isso inclui fatores relacionados \& aqueles que } \\
\text { colocam o paciente em risco para problemas) }\end{array}$ & $\begin{array}{l}\text { Dasconfirmação } \\
\text { Características } \\
\text { Achados da avaliação que } \\
\text { NÃO apoiam a scolha } \\
\text { desse problema }\end{array}$ & $\begin{array}{l}\text { Este problema afeta a } \\
\text { segurança do paciente? } \\
\text { Se sim, como? }\end{array}$ & $\begin{array}{l}\text { Resultados } \\
\text { esperados }\end{array}$ & $\begin{array}{l}\text { Intervenções/ } \\
\text { avaliação }\end{array}$ \\
\hline \multicolumn{6}{|l|}{1.} \\
\hline 2. & & & & & \\
\hline
\end{tabular}

Source: TESORO, 2012 $2^{(7)}$.

Figure 2 - Problem form of the Developing Nurses'Thinking model, culturally adapted for Brazil 
The use of the problem form is suggested as a guide for teaching clinical reasoning and for validating in clinical practice the diagnoses listed here, since students or professionals can list the nursing diagnoses and apply them to fictitious clinical cases or to the person, family, or community they care for. In addition, they can describe the findings that support the problem raised, that is, defining characteristics, risk factors, and related factors ${ }^{(7-8)}$. In the item "non confirmation", the presence of possible clues that do not support the choice of the problem raised for that clinical case or practical situation will be observed. Next, it is important to reflect on the possible impact of the identified problem for patient safety and possible consequences if not addressed. The expected outcomes, nursing interventions, and process evaluation are also listed in the table in Figure 2. By presenting patient safety in the first instance of consideration, the DNT model seeks to prioritize $i^{(7-8)}$.

In the study, therefore, 13 nursing diagnoses chosen based on the theoretical framework of the DNT model were pointed out, going through the seven critical thinking skills: analysis, pattern application, discrimination, information search, logical reasoning, prediction, and knowledge transformation ${ }^{(7)}$. The presented method aims to bring reflection on critical thinking in nursing, through mental processes employed in solving specific problems, together with the employment of repeated practice.

\section{FINAL CONSIDERATIONS}

With this reflection on the concepts of nursing diagnoses and their indicators through critical thinking proposed by the DNT model, we conclude that it is necessary to recognize the importance of incorporating nursing diagnoses and clinical reasoning in all contexts of professional nursing care. Also, it is found that further discussions on the subject are needed in order to validate the nursing diagnoses presented and their indicators in more in-depth studies of experience reports and clinical cases.
Considering that the teaching of clinical reasoning is one of the factors associated with the accuracy with which nurses establish nursing diagnoses, having models and strategies for this teaching is fundamental for the training of professionals capable of providing quality, person-centered care $\mathrm{c}^{(7-8)}$. Further studies with applicability to clinical cases and clinical practice are important regarding the concreteness of the skills presented here, in particular prediction and knowledge transformation skills proposed by the DNT model ${ }^{(8)}$.

Also, it should be noted that this is the first time a pandemic has reached countries that use and study with NANDA-I, Inc. Influenza and Ebola have not been able to reach the epidemiological proportions of SARS-CoV-2, that is, this analysis supports the conclusion that there is a need for discussion based on the perspectives of teaching, research and care practice.

\section{SUPPLEMENTARY MATERIAL}

The article presented was the result of a supplementary material entitled "Nursing diagnoses in cases of coronavirus and COVID-19", a material produced in March 2020 aiming both to provoke the clinical reasoning of nurses on the theme and to disseminate knowledge in search networks and social media. The material received wide organic dissemination and was published on the COREN-ES website. In this sense, this article scientifically reflects the theoretical basis of the path taken for such a conclusion of the nursing diagnoses suggested in the supplementary material ${ }^{(10)}$.

\section{FUNDING AND ACKNOWLEDGEMENT}

We thank the Coordination for the Improvement of Higher Education Personnel - Brazil (CAPES) for its support through a grant from the Social Demand Program (PDS) - CAPES, which contributed to the production of this article.

\section{REFERENCES}

1. World Health Organization (WHO). Coronavirus disease 2019 (COVID-19) situation report [Internet]. [Geneva]: WHO; 2019 [cited 2020 May 13]. Available from: https://www.who.int/emergencies/diseases/novel-coronavirus-2019/situation-reports

2. Conselho Federal de Enfermagem (BR). Nota técnica ${ }^{\circ}$ 01/2020. Orientações sobre o novo coronavírus (COVID-19) [Internet]. Brasília, DF: COFEN; 2020[cited 2020 May 13]. Available from: http://www.cofen.gov.br/cofen-publica-nota-tecnica-sobre-o-coronavirus_77070.html

3. Conselho Regional de Enfermagem de São Paulo (SP). Processo de enfermagem: guia para a prática [Internet]. São Paulo: COREN/SP; 2015[cited 2020 May 11]. Available from: http://www.coren-sp.gov.br/sites/default/files/SAE-web.pdf

4. Conselho Federal de Enfermagem (BR). Resolução ${ }^{\circ}$ 358, de 15 de outubro de 2009. Dispõe sobre a sistematização da assistência de enfermagem e a implementação do processo de enfermagem em ambientes, públicos ou privados, em que ocorre o cuidado profissional de enfermagem, e dá outras providências [Internet]. Brasília, DF: COFEN; 2009[cited 2020 May 15]. Available from: http://www.cofen.gov.br/ resoluo-cofen-3582009_4384.html

5. Nanda International. Diagnósticos de enfermagem da NANDA-I: definições e classificação 2018-2020. 11st ed. Porto Alegre: Artmed; 2018.

6. Szwarcwald CL, Souza Jr PRB, Damacena GN, Malta DC, Barros MBA, Romero DE, et al. ConVid: behavior survey by the internet during the COVID-19 pandemic in Brazil: conception and application methodology. Cad Saude Publica. 2021;37(3):e00268320. https://doi. org/10.1590/0102-311X00268320

7. Jensen R, Cruz DALM, Tesoro MG, Lopes MHBM. Translation and cultural adaptation for Brazil of the developing nurses' thinking model. Rev Latino-Am Enfermagem. 2014;22(2):197-203. https://doi.org/10.1590/0104-1169.3232.2402

8. Mattei AP. Aplicabilidade do model developing nurses' thinking para o desenvolvimento do raciocínio clínico em graduandos de enfermagem [Dissertation] [Internet]. Curitiba: Universidade Federal do Paraná; 2017[cited 2020 May 15]. Available from: http://hdl.handle.net/1884/46987 
9. Tesoro MG. Effects of using the developing nurses' thinking model on nursing students' diagnostic accuracy. J Nurs Educ. 2012;51(8):436-43. https://doi.org/10.3928/01484834-20120615-01

10. Vieira PAAM. Diagnósticos de enfermagem em casos de coronavírus e covid-19 [Internet]. Vitória: COREN/ES; 2020[cited 2021 May 11$]$. [41 slides]. Available from: http://www.coren-es.org.br/diagnostico-de-enfermagem-em-casos-de-coronavirus-e-covid-19_21788.html 